\title{
FORAGING AND FORAGER-RECRUITMENT \\ IN OPHTHALMOPONE HOTTENTOTA EMERY (HYMENOPTERA: FORMICIDAE)*
}

\author{
By W. R. J. Dean \\ FitzPatrick Institute, University of Cape Town, \\ Rondebosch 7700, South Africa.
}

\section{INTRODUCTION}

Ants belonging to the Ponerinae are among the most specialized foragers of the family Formicidae (Wheeler, 1936; Carroll and Janzen, 1973). In Africa, the ponerine ants are predators on other invertebrates, often termites, but also beetles, crickets, other ants and isopods (Prins, 1978; 1985). Two groups in the Ponerine may be recognized: those species which prey on animals of their own body weight or smaller; and, those species which prey on animals larger, often considerably larger, than themselves. This has led to the evolution of different hunting strategies and foraging techniques in the ponerine ants (Wilson, 1958, 1971) with either no forager-recruitment or variations of group-hunting. Foraging techniques in the Ponerinae vary between tribes and within tribes with four main categories, (1) no chemical trails and no forager-recruitment, (2) foragerrecruitment by tandem-running, (3) rudimentary chemical forager-recruitment or short-lived trails, and (4) advanced chemical foragerrecruitment (Wilson, 1958, 1959; Carroll \& Janzen, 1973; Peeters and Crewe, 1987). Closely related species may use different hunting techniques and different forager-recruitment systems. "Recruitment" in this paper is used in a military sense and not demographically.

It has recently been shown by Peeters and Crewe (1987) that Ophthalmopone berthoudi Forel (Ponerinae) is a solitary hunting species, contrary to assumptions in the literature that groupforaging behavior occurs throughout this genus (Wheeler, 1936; Wilson, 1958). There have been no published studies on the diet and foraging behavior of the closely related $O$. hottentota, which occurs in semi-arid southwestern South Africa and Zimbabwe (Prins, 1978).

${ }^{*}$ Manuscript received by the editor February 10, 1989. 
This paper describes the diet and foraging behavior of $O$. hottentota in the semi-arid southern Karoo, South Africa. Other ponerine ants in this area are Anochetus levillanti, Anochetus sp. indet., and an apparently undescribed ponerine, of which only one male has been collected.

\section{StUdy AReA}

Observations of $O$. hottentota were made in semi-arid dwarf shrubland at the Tierberg Karoo Research Center $\left(33^{\circ} 10^{\prime}, 22^{\circ} 16^{\prime}\right)$, Prince Albert, South Africa. The vegetation is dominated by Pteronia pallens, Osteospermum sinuatum and Eberlanzia sp, with succulents (Aizoacae, Mesembryanthemaceae) common and diverse. The annual rainfall averages $170 \mathrm{~mm}$ (100 year mean). Soils are alluvial, silty and deep, but often have gravel patches just below the surface. There are patches of scattered stones derived from the two major geological systems in the area, Witteberg quartzite and Dwyka tillite. Ophthalmopone hottentota occasionally nest under these stones.

Observations of $O$. hottentota were made during December 1987-December 1988. Some nests under stones were opened up and examined, but not mapped or measured.

\section{RESULTS}

Food and foraging behavior

At Tierberg, $O$. hottentota preyed exclusively on one termite species, the polymorphic harvester termite Microhodotermes viator (Latreille) (Hodotermitidae). Termites were taken by the ants at three different sites, but prey-handling techniques were always the same. Harvester termite workers range in weight from 5-39 mg (mean $12 \mathrm{mg}$, SD $6 \mathrm{mg}, \mathrm{n}=27$ ) and soldiers weigh 13-39 mg (mean $27 \mathrm{mg}$, SD $8 \mathrm{mg}, \mathrm{n}=11$ ). Ophthalmopone hottentota foragers range in weight from $16-22 \mathrm{mg}$ (mean $18 \mathrm{mg}$, SD $1 \mathrm{mg}, \mathrm{n}=39$ ). Prey items are therefore approximately the same weight or smaller than the predator if workers are taken, and larger if soldiers are taken. Both workers and soldiers, and, less frequently, nymphs are taken by the ants. Only live prey was taken; $O$. hottentota foragers did not attempt to scavenge dead or severely injured termites.

Microhodotermes viator is common at Tierberg and there are 
numerous colonies with multiple entrances or access holes. This termite forages on the soil surface without any protective earth covering. Plant matter is taken underground through surface-access holes from which the workers emerge and operate at distances of $<1.5 \mathrm{~m}$, bringing plant matter back to the hole and below ground. Plant matter is frequently brought to the hole faster than it can be moved underground.

Ophthalmopone hottentota foragers wait near termite access holes while the termites are foraging, and raid emerging and returning workers. The ants appear to select small or medium-sized termites as potential prey items. In successful attacks the termite is grasped, stung and immediately transported back to the nest. However, the ants are inefficient at catching termites in this situation and sometimes lose the termite which they attack. Termites that escape from $O$. hottentota foragers have been seen to vibrate their abdomens rapidly, which apparently prevents the ant from making a second capture attempt, and which may be pheromone releasing behavior.

Termites are also preyed on at sites where they are excavating underground and pushing soil out onto the surface. Such soil dumps are usually well away from foraging access holes, and are distinctive, with small dark mounds of fresh soil (described by Coaton, 1958). Ophthalmopone hottentota foragers wait at these soil dumps and when there is movement of the soil, indicating that a termite is pushing soil out from below, the ant digs rapidly into the soil mound and removes a termite, which is then stung and transported rapidly to the nest.

The third site at which termites are taken is at diggings of the aardvark Orycteropus afer and bat-eared fox Otocyon megalotis, where the mammals have dug into tunnels or nest-chambers of $M$. viator. The ants 'scout' such places and move freely into the damaged termite nest, returning with termite nymph, worker or soldier prey.

Termite soil dumps apparently provide the most reliable source of food for $\boldsymbol{O}$. hottentota, and a single soil dump may be exploited by several different colonies of ants for several weeks. One such soil dump was being raided by $O$. hottentota foragers from three different nests, and raiding was first observed on 4 February 1988. On 26 February, $O$. hottentota foragers from the same three nests were still 
taking termites from the soil dump. Up to $15 O$. hottentota foragers may be active at a single soil dump, and the average rate of capture at one soil dump was 0.5-1.0 termite/minute for 125 mins of observations. Foragers will move more than $18 \mathrm{~m}$ from the nest to take termites at a soil dump.

The termites have little defense against the ants when pushing out soil. Occasionally soldiers are taken from the soil dumps by $O$. hottentota foragers and these are handled as quickly and as easily as workers and transported to the ant nest.

\section{Forager-recruitment and orientation}

All $O$. hottentota workers foraged singly and there is apparently no recruitment. Foragers returning to the same nest with prey did not share common paths, suggesting that there are no chemical trails laid from the nest to the prey in this species. Foragers apparently use visual cues to orientate, and returning foragers may become disorientated. When returning to the nest, foragers use the most direct path between the prey source and the nest. They frequently stop and turn around through $360^{\circ}$ before continuing to the nest.

Returning, laden foragers enter the nest with their prey, and within a few seconds emerge and return to the prey source. At all nests observed there was no increase in the number of foragers that emerged from a nest after a forager with prey had entered. At one nest, where foragers were taking termite prey from sources diametrically opposed to each other in relation to the nest, single foragers that brought prey back to the nest returned in the direction from which they came, even though one of the prey sources was closer $(<5 \mathrm{~m})$ than the other $(>7 \mathrm{~m})$. This suggests that there is no communication about prey availability between individual ants.

\section{Prey caching}

Six caches of termites were found in O. hottentota nests under stones. In August 1987, a cache containing about 500 dead or immobilized Microhodotermes viator workers and soldiers was found in a nest under a stone. The termites were packed in two layers in a cavity adjacent to the vertical shaft of the ants' nest. There were no larvae present. A second cache, containing about 600 termites, was found in a similar site in December 1987, and consisted of two cavities each about $70 \times 40 \mathrm{~mm}$, each filled with 1-2 
layers of termites. No brood was present. In November 1988 four caches were found under stones and at three of them larvae were present and feeding on the termites in the caches.

\section{Nest sites}

Nine nests were located under stones but the majority of nests (22) were in open ground between, or close to shrubs. All nests were situated within $4 \mathrm{~m}$ of reliable foraging sites (= termite soil dumps).

\section{Colony size}

Two nests of $O$. hottentota excavated at Tierberg contained 30 and 71 workers, respectively, and no queens were found (see Discussion). Colonies may be polydomous as I have two observations of workers carrying other workers to adjacent nests.

\section{Discussion}

Other social insects are rich sources of food for ants (Carroll and Janzen, 1973) and termites are a group that provide prey for a number of different Ponerinae species (Wheeler, 1936; Sheppe, 1970). All obligate termite feeding ants are ponerines (Wheeler, 1936). However, with the exception of $O$. hottentota and Termitopone (Carroll and Janzen, 1973), no ponerines prey on a single species, although species such as Megaponera foetens may repeatedly exploit a single colony of termites (Sheppe, 1970). Possible benefits of the exploitation of a single prey species to the predator include familiarity with handling the prey and where to obtain the prey. However, like other central-place-foragers (Orians \& Pearson, 1979), O. hottentota foragers must still make decisions about load size, since they are dealing with polymorphic prey, and where to catch prey, since harvester termites forage dynamically and unpredictably, and colonies forage asynchronously (pers. obs.) Once a prey source has been located, however, repeated raids on a single colony are probably the most efficient way of exploiting the food source. The unpredictable resource base may not support large colonies of $\boldsymbol{O}$. hottentota and thus more complex prey capture techniques would have been less likely to evolve in this species. Wilson $(1961,1971)$ has suggested that forager-recruitment with chemical (pheromone) trails is more likely to evolve in large colonies than small. Carroll and Janzen (1973) have pointed out the circular reasoning in Wilson's suggestion. 
There are a number of similarities between the foraging behavior of $O$. hottentota and the foraging behavior of $O$. berthoudi, recently studied by Peeters and Crewe (1987). Both species invariably forage alone, and there does not appear to be any co-operation between foragers. Both species are also queenless (Peeters and Crewe, 1985, 1987). There are also important differences between the two species. Peeters and Crewe (1987) note that $O$. berthoudi foragers may sting up to 15 Macrotermes natalensis and Odontotermes badius workers before gathering them up and stinging them again before transporting them back to the nest, although Hodotermes mossambicus prey was caught and transported singly. In the present study, Ophthalmopone hottentota foragers caught, stung and immediately transported their relatively large termite prey to the nest. A difference between the two species is that $O$. hottentota caches prey; this has not been recorded in $O$. berthoudi (Peeters and Crewe, 1987; C. P. Peeters, pers. comm.). Caching of prey by $O$. hottentota and not by $O$. berthoudi may be explained, in part, by the difference in predictability of the prey base of the two species. In the more mesic woodlands where Peeters studied $O$. berthoudi, termites taken by the ants were mainly species that foraged under a protective soil shield, and presumably such termites are always available to $O$. berthoudi foragers which can breach the protective cover. Microhodotermes viator apparently provides a less predictable resource base. At Tierberg, this species foraged sporadically and dynamically (pers. obs.) and, furthermore, will cease surface activity if preyed on by ants or spiders (Coaton, 1958; Dean, 1988). It is postulated that other predators largely dependent on capturing $M$. viator on the soil surface, such as the spider Ammoxenus coccineus (Dean, 1988), will also cache prey. The food-gathering behavior of the termites may be important because they stock-pile plant matter around an access hole and then work within this stock-pile to move the plant material underground. The stockpiling of plant matter on the surface may not be simply a consequence of abundant food, and may be an anti-predator strategy. Both $O$. hottentota foragers and ammoxenid spiders attack termites at the entrance holes but are apparently unable to cope with handling prey and an uneven substratum simultaneously. The behavior of $M$. viator workers which have been attacked but not caught by $O$. hottentota foragers is very similar to the behavioral response of individual Hodotermes mossambicus 
workers under attack, when they are thought to be releasing a warning pheromone (Wilson and Clark, 1977).

Central-place-foraging theory (Orians and Pearson, 1979) predicts that the ants nest will be located as close to a reliable food source as possible. Many $O$. hottentota nests are situated near termite soil dumps, but because the termites forage sporadically and dynamically there may be no advantage to individual $O$. hottentota colonies in locating near a termite nest. However, there could be marginal benefits to the $O$. hottentota colony situated near a termite soil dump in that prey will be available at a short range for at least part of the time. The tenets of central-place-foraging theory could be further investigated in this species.

\section{ACKNOWLEDGMENTS}

I am grateful to Sue Milton, Roy Siegfried, Christian Peeters and Phil Hockey for comments on a draft of this paper, and to Dr. A. Prins (South African Museum) for identifying ant specimens. This research was funded by the Terrestrial Ecosystems Programme, FRD, CSIR.

\section{REFERENCES}

ARNOLD, G.

1915. A monograph of the Formicidae of South Africa. Part 1 (Ponerinae; Dorylinae). Ann. S.A. Museum, 14: 1-163.

Carroll, C. R. \& D. H. Janzen

1973. Ecology of foraging by ants. Ann. Rev. Ecol. Syst., 4: 231-257.

Coaton, W. G. H.

1958. The hodotermitid harvester termites of South Africa. Dept. of Agriculture Science Bull., 375: 1-112.

DEAN, W. R. J.

1988. Spider predation on termites. J. ent. Soc. sth. Afr., 51: 147-148.

Orians, G. H. and N. E. Pearson

1979. On the theory of central place foraging. In: Analysis of ecological systems. (ed. D. J. Horn, G. R. Stairs and R. D. Mitchell) Ohio State University Press, Columbus pp. 155-177.

Peeters, C. ANd R. Crewe.

1985. Queenlessness and reproductive differentiation in Ophthalmopone hottentota. S. Afr. J. Zool., 20: 268.

Peeters, C. AND R. Crewe.

1987. Foraging and recruitment in ponerine ants: solitary hunting in the queenless Ophthalmopone berthoudi (Hymenoptera: Formicidae). Psyche, 94: 201-214. 
Prins, A. J.

1978. Hymenoptera. In: Biogeography and ecology of Southern Africa. (ed. M. J. A. Werger) W. Junk, The Hague pp. 825-875.

Prins, A. J.

1985. Formicoidea. In: Insects of Southern Africa. (ed. C. H. Scholtz and E. SHEPPE, W. Holm) Butterworths, Durban pp. 502.

1970. Invertebrate predation on termites of the African savanna. Insectes Soc., 17: 205-218.

WHEELER, W. M.

1936. Ecoogical relations of ponerine and other ants to termites. Proc. American Academy Arts and Sciences, 71: 159-243.

WILSON, E. O.

1958. The beginnings of nomadic and group-predatory behavior in the ponerine ants. Evol., 12: 24-31.

WILSON, E. 0 .

1959. Communication by tandem-running in the ant genus Cardiocondyla. Psyche, 66: 29-34.

WILSON, E. O.

1971. The insect societies. Belknap Press, Cambridge, Mass.

Wilson, D. S. AND A. B. Clark

1977. Above ground predator defence in the harvester termite, Hodotermes mossambicus (Hagen). J. ent. Soc. sth. Afr., 40: 271-282. 

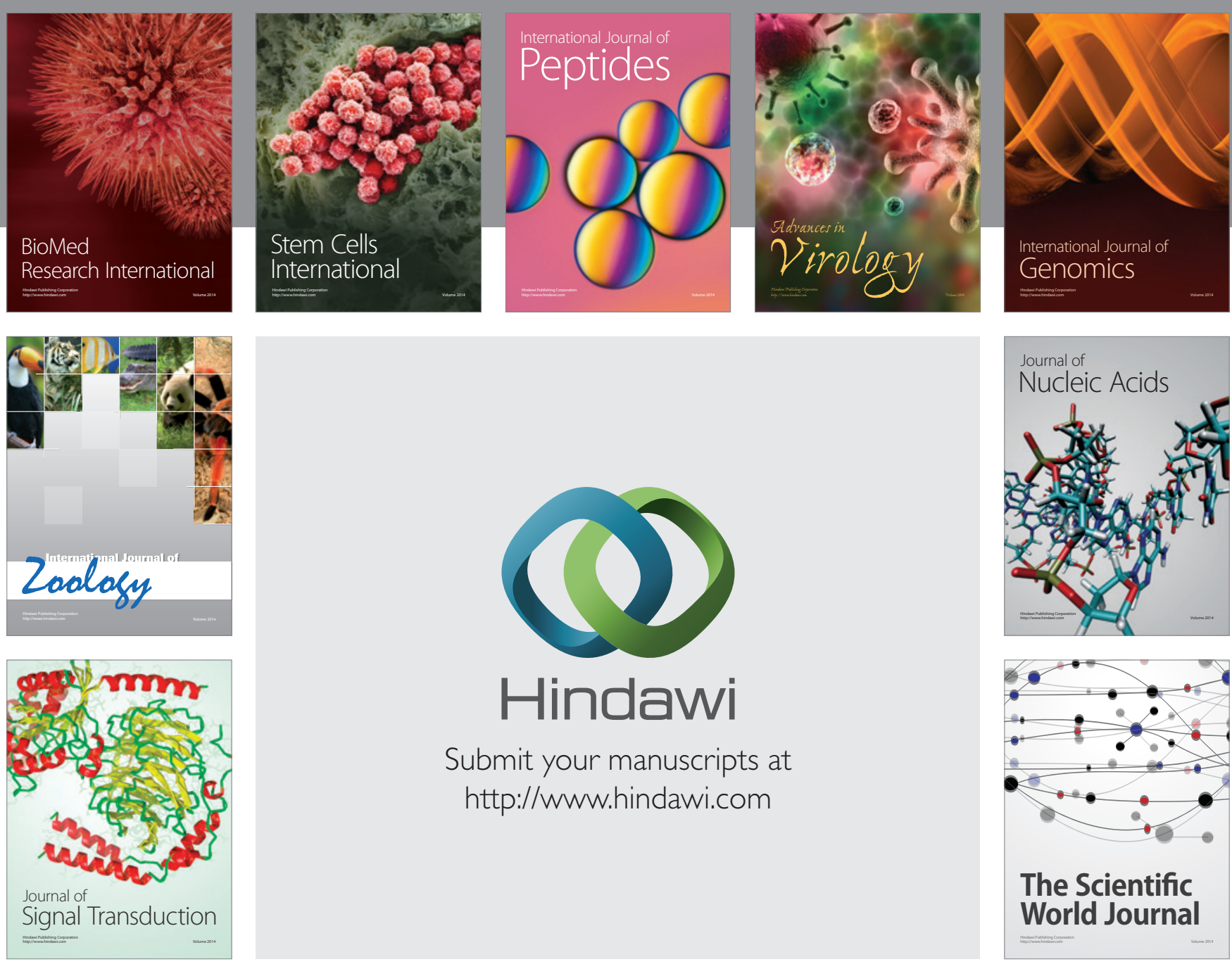

Submit your manuscripts at

http://www.hindawi.com
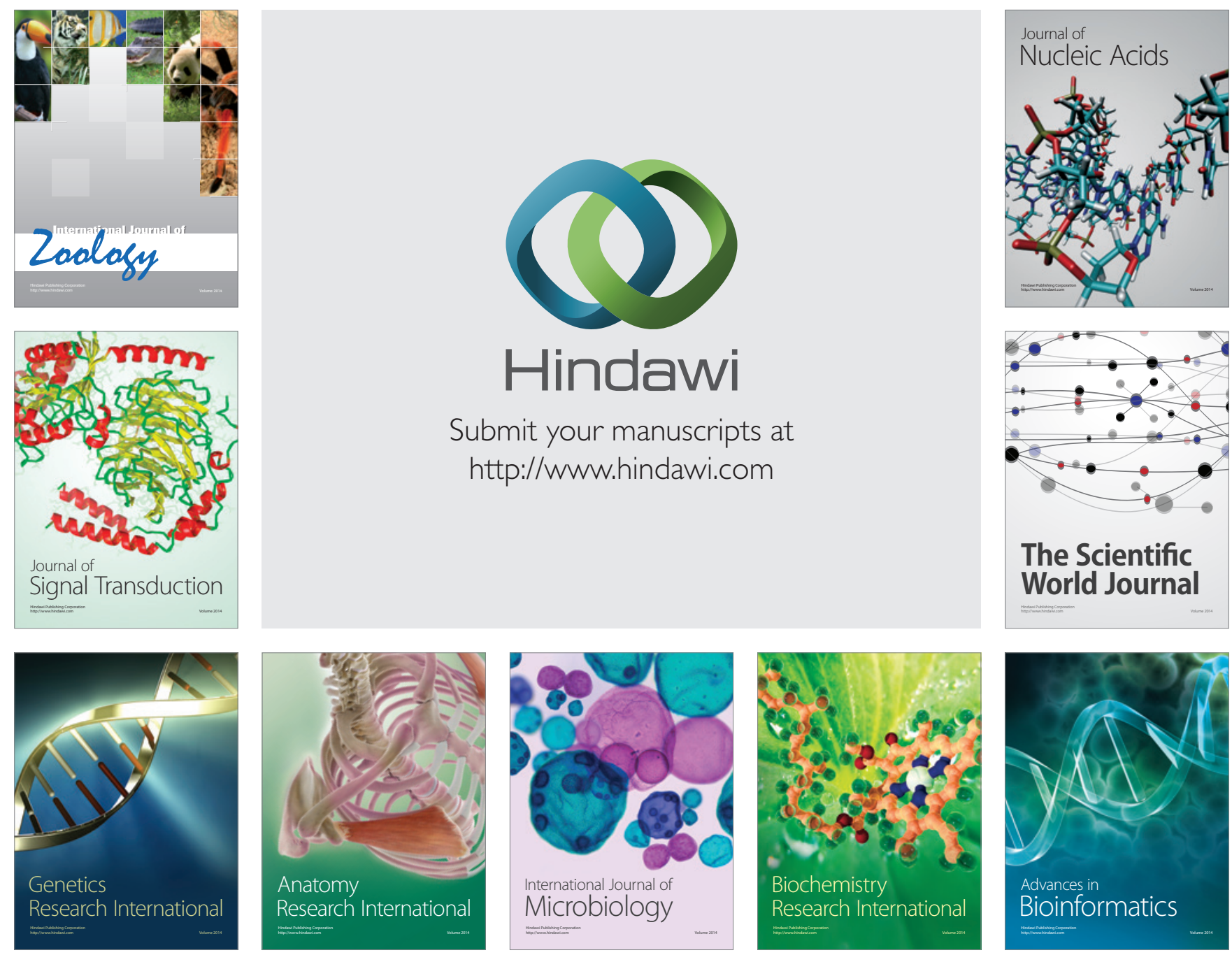

The Scientific World Journal
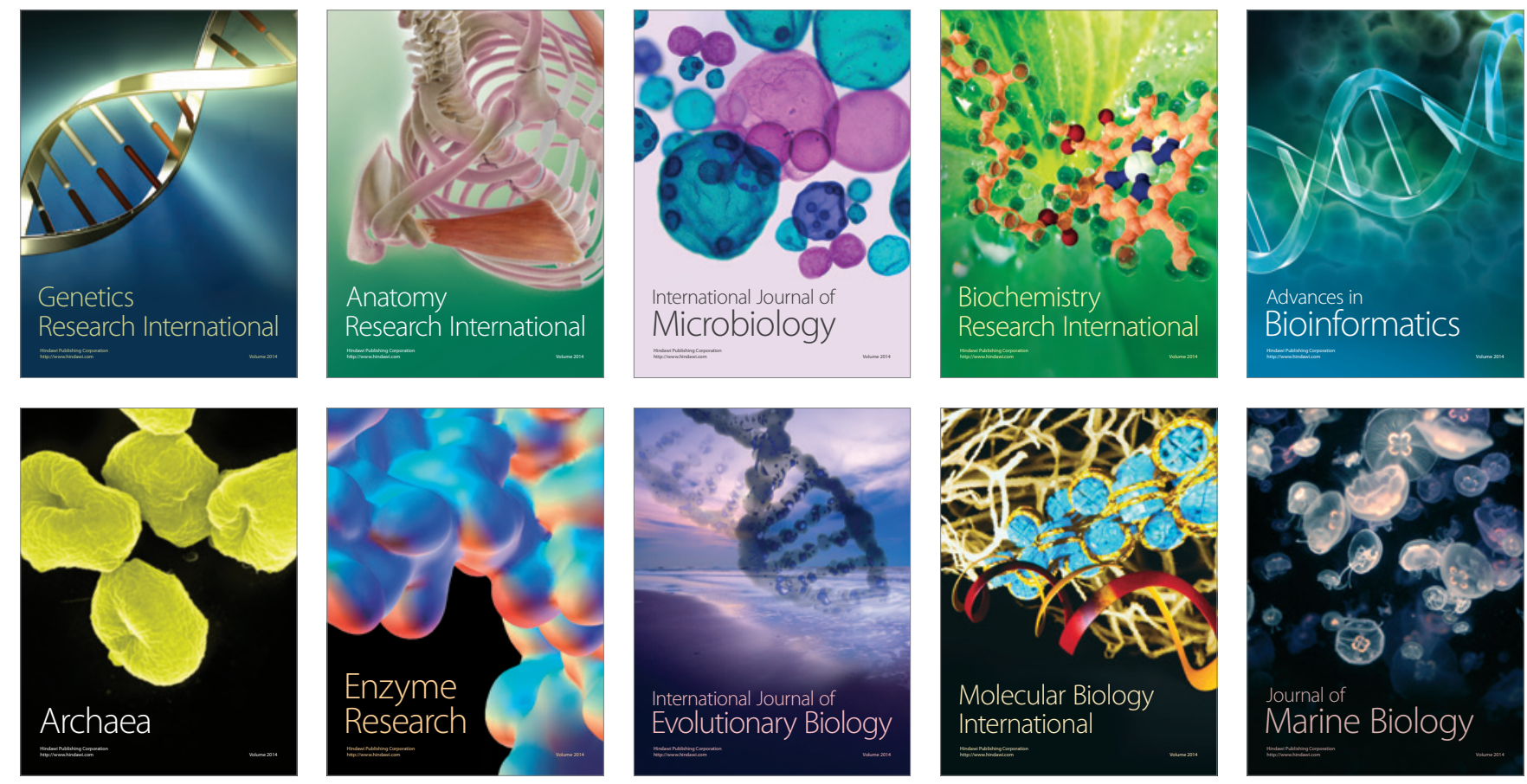